\title{
Turyn: oblicza miasta. W kierunku smart
}

\section{Turin: faces of the city. Towards the smart}

\section{Streszczenie}

Juryn to miasto o silnych korzeniach antycznych i średniowiecznych - miasto kościołów i pałaców. Miasto kultury, biznes S

\section{Abstract}

Turin is a city with very strong ancient and medieval roots-a city of churches and palaces. A city of culture, business and sports-one that is monumental, elegant and cool, while at the same time being fascinatingly modest. The capital of Piedon the Po River, a city of great architects: Juvarra, Guarini and Alfieri, today constitutes one of the best lessons on post-Baroque urban planning. A city of many faces, in which the past mixes itself with a smart future.

Stowa kluczowe: barok, Turyn, monumentalizm, wnetrze urbanistyczne, oś miejska, krajobraz, rewitalizacja, tereny poprzemystowe
Keywords: Baroque, Turin, monumentalism, urban interior, urban axis, the landscape, urban regeneration, post-industrial areas

Turyn to miasto do niedawna nieco zapomniane i pop-turystycznie niedoceniane. Miasto o silnych korzeniach anycznych i średniowiecznych - miasto kościołów, pałaców muzeów - z największym po Kairskim muzeum egipskim ha świecie - położone nad majestatyczną rzeka Po'. Nie jest miejscem najchetniej odwiedzanym przez turystów i nieczeto pojawia sie na pierwszej pozycii miejsc polecanych we Włoszech Bardziej pociagian sa miasta toskáskie, umbryiWhe lub liguryskie ze swoja zawita tkanka: zmienna, zlozion We i pelna niespodza ze swoja zawha lkakg: zmiena, zozona czony, geón

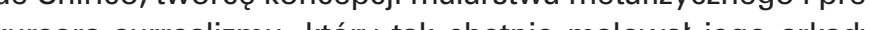
i podciena. Tu dorasta i dojzewar Jean Jacaues Roussedy i podcienia. Tu dorasta i dojzewat Jean Jacques Rousseau, tutaj studiowal Umberto Eco. Turyn na tle pocztowkowych ikolorowych citta italiane jest miast na chlodnym, nieszabloowym i skromnym, a jednoc

\section{Lekcja urbanistyki}

Założyli go w IV wieku p.n.e. Turyńczycy - plemię celtycko-galljskie dzielnie stawiające czoło kolejnym najezdżcom: od Hannibala aż po Rzymian, którzy ostatecznie po swoim zwy cięstwie wznieśli tu miasto W I wieku n.é2. Castrum pełniące rolę militarną powstało na planie czworokąta i zostało oto-
Turin is a city that until recently has been someWhat forgotten and underappreciated in terms of popular tourism. A city with strong ancient an museums - with the largest Egyptian museum in the world right after the one in Cairo-located on he majestic Po river. It is not the most eagerly visted place by tourists and it does not show up as the first tourist destination in ltaly too often. Tus urban tissue: that is changing, complex and full of surprises, are much more attractive. The perfect Turin, with its infinite, geometric decor, would rather fascinate Giorgio de Chirico, the man who was the precursor of surrealism so often painting the city's arcades. It was here that Jacques Rousseau grew up and matured, while to Umberto Eco thas a place where he studied. Turin, against the

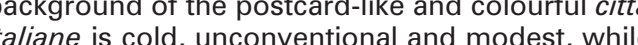
simultaneously being rich and elegant.

A lesson in urban planning
It was founded in the fourth century BCE by the a Celto-Ligurian Alpine tribe that bravely from Hannibal to the Romans, who, ultimately, after heir victory, erected a city here in the first century

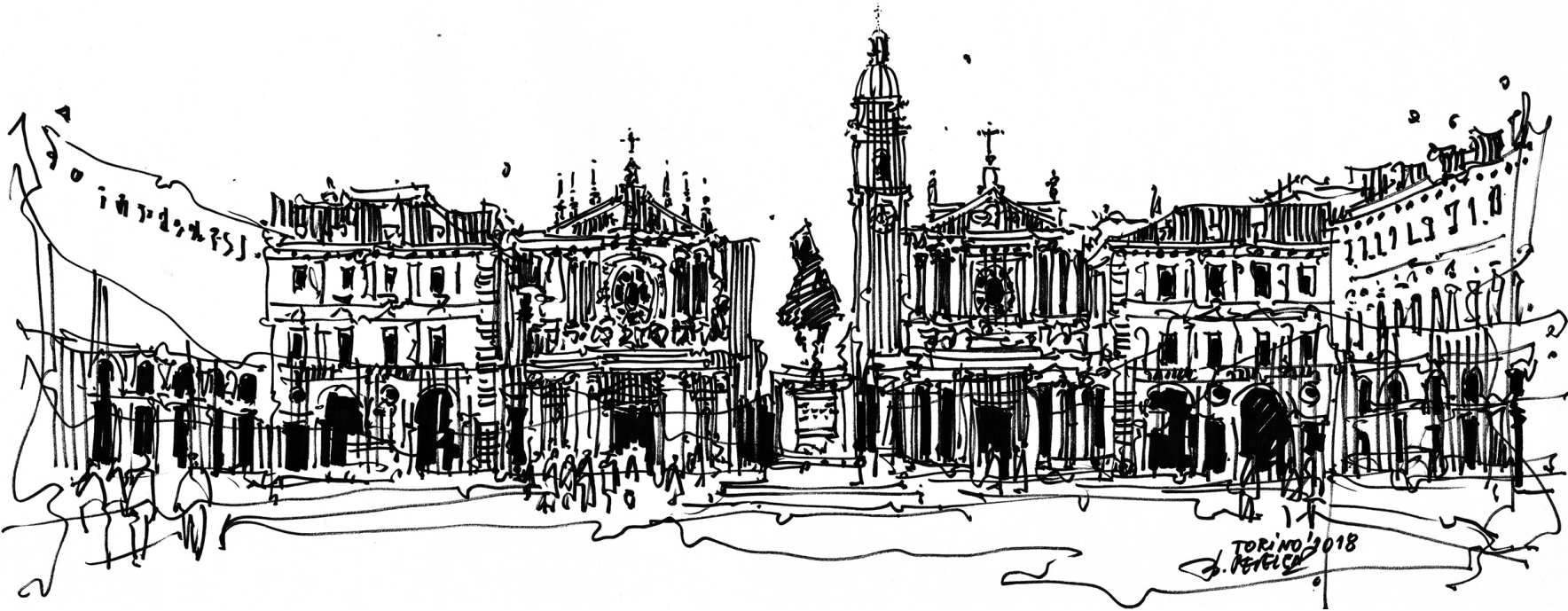

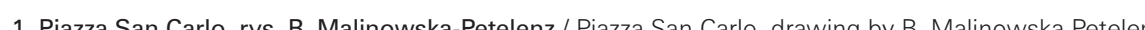

czone murami. Do dzisiejszych czasów zachowała się Porta Palatina $z$ I w. n.e. jako jedna z bram wjazdowych do miasta oraz regularny układ siatki urbanistycznej ${ }^{3}$. Od średniowiecza Turyn pełnit istotną funkcję - najpierw jako stolica państwa Lon Sardynii. Z łote las Turynu jako stolica Piemontu Xrólestwa kiedy to na krótko stał sie stolica jedn Włoch. Wraz z późniejsza utrata joli politycznej wzmogła sie industrializacja miasta, które odtąd jest istotnym ośrodkiem Whe odtąd jest

Do Turynu zieżdzaja licznie miłośnicy i smakosze sztuki bu dowy miast - architekci i studenci wydziałów architektury. Tu można spotkac jedyne w swoim rodzaju, charakterystyczne sekwencje wnetrz - wielkich ulic - zbudowanych na twardej, prostokreślnej siatce miejskiej. Tutaj także w sposób modelowy sprzegła sie natura z wielka kultura: w Turynie bowiem na przełomie XVIII i XIX w. urbanistyka barokowa polegająca na wiązaniu struktur miejskich z otoczeniem naturalnym, stała się w pełni dojrzała.

Dażenie do monumentalnych, reprezentacyjnych rozwiazań przemyślnie zakomponowanych jest tu widoczne niemat w każym miejscu. Prostokatna, neoklasyczna sieć ulic, zano muzea. Ciągi uliczne i place wzbogacone są szczegoln "wartoscią dodaną" - dzięki swoim naturalnym otwarciom

pch wnętrz tego mia sta jest Piazza San Carlo - podcieniowy, podłużny, o proporcjach niewiele ponad dwoch kwadratow (160x70m). Nanizany na długą os Via Roma, łączy się w prostej linii: od południa z półokrągłym, wydłużonym Piazza Felice i Giardino Sambuy oraz dworcem Porta Nuova, od północy zaś z sercem miast - Piazza Castello. Podobnie jak w rzymskim Piazza del Popolo, plac ten od strony południowej flankują dwa bliźniacze a rectangular plan, and was surrounded by walls,

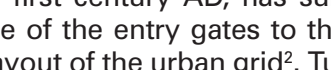

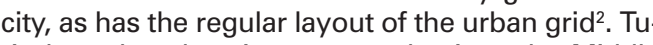
in has played an important role since the Middle Ages-first as the capital of the state of the Lomyed its golden years in the 1860 's, when it briefly became the capital of Along with he later loss of Turin's pollical role, the come al essentialindustrial and scientific centre Turin is being visited by large numbers of lovers of the art of the construction of cities-architects and students of archinectural faculties. It is here that we cs of interior greats treets built un sequencorthogonal urban grid. It is also here that nature has become tied with high culture in a model manner: it was in Turin that Baroque urban planning watural surroundings, became fully mature at he turn of the eighteenth and nineteenth century. A tendency for monumental, representative and intelligently composed solutions is visible here in almost every place. The rectangular, neoclassicis creates rich interiors by constituting a phenom enal frame for landmarks and accentuating public buildings, like the numerous churches, palaces, galleries and museums. Sequences of streets value"-thanks to their natural visural openings toowy peaks of the Alps.

One of the most important and beautiful interiors of this city is Piazza San Carlo-featuring arcades and 政 Placed upon the long axis of Via Roma it connects 列 warlice and Giardino Sambuy from the south, as We Similarly as in the Roman Pizzza del Popase, this the Kingdom of ltaly which was uniting at the time. 
barokowe kościoły: San Carlo Borromeo i Santa Cristina Interesującym elementem tej pierzei jest złamana symetria: tylko San Carlo posiada wysoka dzwonnice, stanowiąca silny kontrapunkt $w$ tym monumentalnym wnętrzu.

Kwadratowy Piazza Castello ${ }^{4}$ wraz z pałacem królewskim i Palazzo Madama ${ }^{5}$ oraz kościołem San Lorenzo Guarino Guariniego ${ }^{6}$, stanowi początek tańcucha wnętrz, zróżnicowanych typologicznie. Miejsce to łączy się z imponującą struktura wnętrza ulicy Po, wielkiej miejskiej osi, silnie zdefiniowanej podcieniami. Wzdłuż tej alei, diagonalnie wytyczonej względem kwadratowych kwartałów, rozmieszczone są dwa przepyszne barokowe kościoły - silnie akcentowane, klasycznie wbudowane w ściane wnetrza ulicy. Pierwszy $z$ nich - S. Francesco Da Paola - cofnięty wzgledem wnetrza, otrzymat zgrabne przedpole rozbijając ciagtość pierzei. Drugi - Chiesa Della Santissima Annunziata ${ }^{7}$ nie łamie kontinuum długich sa Della Santissima Annunziata’ nie łamie kontinuum długich elewacji, włączony w partię podcieniową ulicy, wyróżnia się
niebywałym bogactwem detalu, wspaniałą tektoniką elewacji niebywałym bogactwem deta
i uskokowym pilastrowaniem

Ten długi 740-metrowy korytarz urbanistyczny fascynuje silnie zarysowanymi konturami i rytmem podcieni spotęgowanym jednolitym rozmiarem okien $w$ bogatych opaskach $z$ trójkątnym naczółkiem Podcienia kryją w sobie liczne księgarnie i antykwariaty, sklepy ze starymi mapami i płytami winylowymi. To miasto bukinistów.

Ciągłość pierzei jest kontynuowana na styku z każdą prostopadłą ulica, nad ktorą przebiegaja podcienia o nieco innym rozstawie arkad niż w przypadku kamienic. Ulica Po prowadzi do umiarowego, wydłużonego placu Vittorio Veneto, kolejnej reprezentacyjnej przestrzeni publicznej, by nasteppnie zyskać przedłużenie w postaci kamiennego mostu Vittorio Emanuele. Ta niezwykła sekwencja i wielka oś kończy się w perspektywie majestatycznym, osiowo usytuowanym, okragłym kościołem Gran Madre di Dio ${ }^{8}$ Ta klasycystyczna światynia zbudowana została w latach 1827-1831 dla upamietnienia powrotu do Wtoch Wiktora Emanu L Przy jej budowie architekt - Ferdinando Bonsignore - inspirowat sie architektura rzymskie go Panteonu. Do we na szczycie których Gran Madre trzymajaca kielich. Stad rozciaga sie olsnewa Gra widek try symbolem - charakterystyczną Mole Antonelliana', dzisiaj symbolem - charakterystczna Mole Antoneliana Muzeum Kinematografil.

Efektownym dopetnieniem i modelową ilustracją artystycznego mariażu natury $\mathrm{i}$ kultury - jest lokalizacja turyńskiej postbarokowej, kopułowej Basilica di Superga (1717-1731), kolejnego symbolu stolicy Piemontu, z rozmachem wzniesionej na wzgórzu Superga ${ }^{10}$. Jest to dzieło Filippo Juvarry, messyńskiego architekta, wykształconego w Rzymie, którego wiele pojedynczych realizacji, a także zespołów urbanistycznych mozna podziwac w Turynie. Bazylika wraz z kościolem Gran Madre di Dio i usytuowanym na wzgórzu Monte de Cappuccini - pozznorenesansowym klasztornym kościołem Santa Maria del Monte"1" tworzą najwyższej próby krajobrazowo-urbanistyczny łańcuch obiektów o wybitnych walorach estetycznych, usytuowanych na tle zielonych wzgórz wzno- square is flanked by twin Baroque churches: San Carlo Borromeo and Santa Cristina, with wonderfu interiors that appear heavy from their rich details an broken symmetry: only the San Carlos Church possesses a tall bell tower, which constitutes a strong counterpoint in this monumental interior.

The square Piazza Castello ${ }^{3}$, along with the royal palace, Palazzo Madama ${ }^{4}$ and the San Lorenzo of a chain of typologically varied interiors. The site is connected with the impressive structure of $\mathrm{Po}$ Street, a grand urban axis, strongly defined by arcades. Along this avenue, diagonally outlined in $r$ Baroque churches-strongly accentuated, classcally incorporated into the wall of the interior of the street. The first of these- - . Francesco Da Paolarecessed in relation to the interior, was given an
elegant foreground that breaks apart the continuity elegant foreground that breaks apart the continuity
of the frontage. The second - Chiesa Della Santissma Annunziata ${ }^{6}$, does not break up the continuum of the long facades, incorporated into the arcade section of the street, it stands out with an extraorof its facade and stepped pilasters.

This long, 740 -metre-long urban corridor fascinates us with its strongly outlined contours and the rhythm of arcades, magnified by the uniform size of windows encircled by rich frames with triangubook and antique shops, stores with old maps and vinyl records. It is a city of bouquinistes.

The continuity of the frontage continues at the point of contact with every perpendicular street, above which there are arcades with a slightly differen
spacing than in the case of townhouses. Po Street spacing than in the case of townhouses. Po Street
leads to the neat, elongated Vittorio Veneto squar another representative public space, in order to then become extended in the form of the stone Vittorio Emanuele street. This extraordinary sequence
and grand axis ends in its perspective by the ma-
jestic, axially placed and circular Gran Madre di Dio Church? This classicist temple was built in the years $1827-1831$ in order to commemorate the return of
Victor Emanuel I to Italy. During its construction, its $V$ ictor Emanuel It Italy. During its construction,
architect, Ferdinando Bonsignore, became inspired by the architecture of the Roman Pantheon. Monu-
mental stairs lead to its entrance, at the top of which are characteristic sculptures with the Gran Madre statue, holding a chalice. From here on out there stretches an enchanting view of the city, decorated
by a meticulous weave of towers and domes, as which today houses the Cinematography Museum. The location of Turin's post-Baroque, domed Basilica di Superga (1717-1731) - another symbo of the capital of Piedmont, expansively built atop
Superga Hill, is an impressive culmination and model illustration of the artistic marriage between nature and cultures. It is the work of Filippo Juvarra, a Messinian architect who had been educated in Rome and whose many individual built projects, as
well as urban complexes, can be marvelled at in rin. The basilica, along with the Gran Madre di Dio Church and the late-Renaissance monastic Santa Maria del Monte Chruch ${ }^{10}$ located atop Monte de Cappuccini, create a landscape and urban chain of against a background of green hills towering over the Po river. Superga is also an excellent observation point, from where we can marvel at the entire szących się nad rzeką Po. Superga jest również znakomitym żna podziwiać całe miasto tle ośnieżonych szczytów Alp.

\section{Dialogi miejskie, czyli nowe $w$ starym}

Dzisiejszy Turyn to prawie milionowe miasto i jedna ze stolic europejskiego przemysłu. Zaliczany jest do miast europejskich, które słyną z udanych prób wpisania kluczowych projektów rewitalizacii obszarów zdegradowanych w ogóln trategie rozwoju (Barcelona Berlin, Hamburg, Lyon $\mathrm{Na}$ Mediolan ${ }^{12}$. Obszay przenystowe tutaj wciaz podlegaja roz

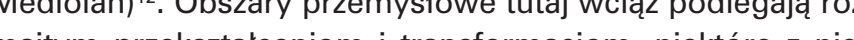
ść z nich adaptuje zastane dziedzictwo w celu m.in. zachowania pamięci historii ozwoju tych obszarów ${ }^{13}$.

Turyński Environment Park powstał w obszarze Valdocco, w ramach programu rewitalizacji Spina3 w $1996 \mathrm{r}$. i jest efek-

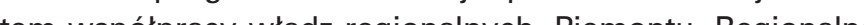
Agencii Rozy wu, Politegniki Turýn rkiejontu, Regionalnej ryńskiego. Budowe porku wi Turyńskiej i Uniwersytetu Tuw 70\% z Budowę parku w latach 1997-2000 stinansowano wo\% z funduszy unijnych'. Na zdegradowanych terenach poprze mystowych, w sąsiedztwie wioski olimpijskiej, archi$z$ wielofunkcyjnym zespołem sportowo-rekreacyjnym. Głów nym zalożeniem bylo zachowanie oryginalnych form zabyprzy rzece Dora w ramach projektu „Torino - Città d'Acqua". W centrum kompozycyjnym całego założenia stanął kośció Santo Volto' ${ }^{16}$ autorstwa Mario Botty - dziś ikona miasta. Zrewaloryzowany teren podzielono na pięć części o zróżnicowanym charakterze zaś elementem scalającym całość jes rzeka Dora. Centrum parku tworzy dużych rozmiarów hala przemysłowa po dawnej hucie Vitali. Szeroka promenada $z$ pergolami $i$ zadaszeniem w postaci koron drzew taczy park z sąsiednią dzielnicą. Specjalnymi rampami można przedostac sie do oddzielnej strefy przeznaczonej do realizacii różnorodnych dzigń spolecznych. Stalowe stupy w kolorze ciennopo-

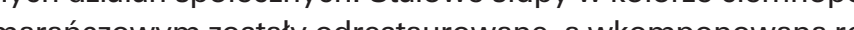
industrialne przestrzeni publicznej. Betonowe wieże i fundamenty zostały przekształcone w fantastyczne place zabaw. Zastosowani ch drzew kwitnacych nie tylko wzbogaca środowisko ale ównież oferuje przyjemne widoki na miejski krajobraz.

Kościół z parkiem łączy szeroka kładka (wschód-zachód) o długości $700 \mathrm{~m}$ przerzucona nad ruchliwą arterią Via Borgaro. Platforma obserwacyjna umożliwia zaobserwowanie panoramy miasta, przy dobrej widoczności, od strony wschodnie można dojrzeć słynny symbol Piemontu - bazylikę Superga. Turyński zespół sakralny wraz z kościołem to przykład nawiązania do tradycji klasztonych " , co Botta konsekwentnie stosuje w wielu innych swoich sakralnych realizacjach (Evry, Pordenone, Merate, Seriate). Monumentalna struktura światyni, wzniesiona na planie centralnym, z zewnątrz prezentuje się jako siedmiowieżowa bryła. W każdej $z$ wiez mieści sie kaplica, od gory przeszklona. Industrialny charakter założenia podkreśla smukły komin byłej huty stali, pełniący funkcje campanilli zwieńczonej krzyżem, owiniętej spiralną struktura. city against the background of the snowy peaks of the Alps.

Urban dialogues, the new inside the old most one million and one of the capitals of European industry. It is counted among those Europea cities that are famous for their successful attempts
at blending key urban regeneration projects concerning decayed areas into their general development strategy (Barcelona, Berlin, Hamburg, Lyon, Nantes, Milan) ${ }^{11}$. Industrial areas still undergo
various changes and transformations here, while various changes and transformations here, while
some take on the shape of outstanding works. Most of them adapt existing heritage in order to, among other things, preserve the memory of the history of the development of these areas'

Thea, Environment park was built in the Valdocco programme in 1996 and is the result of the cotio ration of regional authorities, Piedmont the Regional Development Agency, the Turin University of Tendsology and the University of Turin. $70 \%$ of the

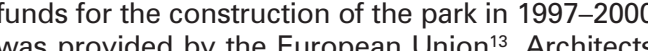
from the Latz+Partner company designed an urban ounds, in the vicinity of the Olympic village. The main objective was the preservation of the original industrial forms
and restoring the areas near the Dora river as a part

The Santo Volto Church 15 by Mario Botta-now an icon of the city-was placed at the compositiona centre of the entire layout.

The regenerated area was divided into five parts,
each with a varied character, while the element each with a varied character, while the element
that binds the entirety is the Dora River. The centre of the park is composed of a large industrial hal that used to be a part of the Vitali steel mill. A wide promenade with pergolas and a covering in the
form of tree crowns connects the park with the zone meant for performing various social activities using special ramps. Steel columns in a dark orange colour were restored, while greenery, ners of activity within this industrial public maninto fantastic playgrounds. The use of numerous blooming trees not only enriches the environment,
but also offers pleasant views of the urban landscape. The church is connected with the park by a wide (east-west) with a length of $700 \mathrm{~m}$, observation platform makes it possible to observe the panorama of the city, while in times of good
visibility we can see the famous symbol of Piedmont from the east-the Superga Basilica. Turin's religious complex, along with the church, is an example of a reference to monastic traditions something that Botta consistently uses in many of
his religious projects (Evry, Pordenone, Merate, Seriate). The monumental structure of the temple, erected on a central plan, presents itself from the outside as a massing with seven towers. In each
of them there is a chapel with a skylight. The industrial character of the complex is highlighted by
the slim smokestack of the former steel mill, which plays the role of a campanile crowned by a cross. shrouded in a spiral structure. 
Całe założenie urbanistyczne kościoła Santo Volto, dzięki swej w otaczającym wnętrzu urbanistycznym. Również sama bryła kościoła jest formą mocną o silnym polu działania formalnego ze względu na swój kształt i spoistość.

Architektura Botty bierze poczatek $z$ form pierwotnych, zdradzając niezwykła wrażliwość na kontekst i specyfike miejsca w którym powstaje - architekt śmiało operuje materiatem genetycznym miejsca i postugujac sie nowy twozywem, kreuje nowe zestamieni kompozycyjn ${ }^{18}$. W tym przypadku, kreustrzeń postindustia forme śmi Volto w Tury. zaviera sie whasie w takin indust przo why ing przedziwym wezcz sura wytworzly spóny i cal ciowy obraz miejsca, zywą, tętniąca energia przestzen publczna, a takze - zgodny z tradycja - rozpoznawalny i lan py do zapaniętania landmark miasta Turyn. Nowopowstala przestzen publiczna sprzęzona z krajobrazem parkowym wraz z pozostalościami ruin przemyslowych stanowią glówne elementy tożsamości tego miejsca'

Reutylizacja zdegradowanych obszarow przemysłowych przeznaczonych do rozbiórki obejmująca dawne fabryki, dworce kolejowe, hale targowe, doki, a nawet kopalnie czy huty dziś staje się normą. Obiekty takie adaptuje się na hotele i mieszkania, a takze placowki naukowe lub kulturalne. Sukces przedsięwzięcia zależy często od zaangażowania uznanych gwiazd architektury (np. Herzog \& de Meuron w przypadku Tate Modern). Tak również stało sie ze słynną juz historyczną fabryką Fiata ${ }^{20}$, którą na nowo zaadaptował Renzo Piano ${ }^{21}$. Całą przestrzeń zagospodarowano i podzielono na strefy ekspozycji przemystowej i handlowej, centrum konferencyjne, lotnisko dla helikopterów, przestrzenie dla małych przedsiebiorstw, restauracje, ogrody, bary, hotele i siedziby wydziatów Uniwersytetu Turyńskiego22 . Dzisiaj Lingotto - fabryka która niegdyś tak zauroczyła Le Corbusiera, stała sie swoistym smart-miasteczkiem": kina i muzyki, kongresów i wystaw. To takie nowy ó́rodek sztuki - Pinacoteca Giovanni e Marella Agnelli, która wznosi się nad torm próbnym obok szkla Agnelli, ky wzick kuli, fón jak Modigliani, Tiepolo, Balla, Matisse, Renoir i Canaletto.

Trudno tu nie wspomnieć o innej realizacji Renzo Piano, który w swojej twórczości stara się odpowiadać na problemy związane z polityką zrównoważonego rozwoju w oryginalny, własny sposób - ale pozostając $w$ zgodzie $z$ filozofią zielonej architektury $i$ technologii high-tech ${ }^{23}$. To wieża Intesa Sanpaolo Tower z bioklimatycznym system klimatyzacji i wentylacj opartym o naturalny przepływ powietrza ${ }^{24}$. Ow nowy inteligentny, turynski wiozowiec zlokalzowano na obrzeżach historycznego srodmiescia. Budynek, o wysokości ponad 166 metrów, miesci siedzibę glówną i biura wszystkich podstawowych komorek organizacyjnych banku Intesa Sanpaolo. Elewację wschodnią i zachodnią zaprojektowano jako dwuwarstwowe, z żaluzjami sterowanymi mechanicznie w celu kontroli dostępu światła słonecznego i regulacji przepływu powietrza. Południową zaś w całości obłożono panelami fotowoltaicznymi o łącznej powierzchni około $1600 \mathrm{~m} 2$. Niestety,
The entire urban complex of the Santo Volto Church, thanks to its compositional structure and surrounding , creates a pow. The form within the church itself is a strong form with a powerful zon of formal influence due to its shape and density. Botta's architecture has its origins in primal forms, betraying an extraordinary sensitivity to the contex architect boldly operates using the genetic materia of a site and, using the new material, creates new compositional sets ${ }^{17}$. In this case the post-industria space and the structure that had existed within axpression form of the temple. The neomodernit tained within such an industrial, even weird, surrea decor. The church and park established a cohesive and holistic image of the place, a living public space that teems with energy, as well as-in accordance ber landmark of the city of Turin. The newly buit public space linked with the park landscape alon with the remains of post-industrial ruins constitute the main elements of the identity of this place $e^{18}$. demolition decayed industrial areas assigned for tions, shopping halls, docks and even mines or steel mills is currently becoming the norm. Such structures are adapted into hotels and apartments as well as scientific and cultural facilities. The success of a project often depends on the involvement
of renowned stars of architecture (e.g. Herzog \& de Meuron in the case of Tate Modern). This is also what happened with the famous and currently historical Fiat factory 19 , which was adapted by Renzo vided into industrial and retail exhibition and $\mathrm{a}$ a conference centre, a helicopter landing facility, spaces for small businesses, restaurants, gardens, bars, hotels and faculty buildings of the University of Turin'2. Today, Lignotto- the factory that once town": of cinema and music, congresses and exhibitions. It is also a new centre of the arts-the Pinacoteca Giovanni e Marella Agnelli, which towers over the testing track around the glass sphere, also by Renzo pinty in the gallery but they inclue works by such masters like Modigliani, Tiepolo, Balla, Matisse, Renoir and Canaletto. It is difficult not to mention a different built project by Renzo Piano, who attempts to find answers to problems associated with the policy of sustain-
able development in an original manner-but while remaining in concordance with the philosophy of green architecture and advanced technology $y^{22}$. It is
the Intesa Sanpaolo Tower, with a bioclimatic systhe Intesa Sanpaolo Tower, with a bioclimatic sys-
tem of air-conditioning and ventilation based on tem of air-conditioning and ventilation based
natural airflow ${ }^{23}$. This smart tower was placed on
the outskirts of the historical downtown area of Tu rin. The building, with a height of over 166 metres, houses the main headquarters and the offices of all the basic organisational cells of the Intesa San-
paolo bank. The eastern and western facades were designed as double-skin facades, with mechanically controlled blinds meant to control access to sunlight and regulate airflow. The southern facade, in turn, was entirely clad in photovoltaic panels
with a combined surface of around $1600 \mathrm{~m}^{2}$. with a combined surface of around $1600 \mathrm{~m}^{2}$. Un-
fortunately, the building, due to its height, largely disrupts the previously harmonious panorama of
ditumately the city. budynek, z racji swojej wysokości w znacznym stopniu rozbija, dotychczas harmonijną panorame miasta.

Ciekawym przykładem modernizacji jednego z najstarszych muzeów o tematyce samochodowej na świecie - Museo dell'Automobile ${ }^{25}$ - jest projekt architekta Cino Zucchi' ${ }^{26}$. Nowoczesny, późno modernistyczny obiekt został w 2011 roku poddany gruntownym pracom remontowym i renowacyjnym, a także powieksszony o nowe skrzydło. Nowy obiekt nie konkuruje z istniejaca bryta lecz formalnie stanowi jego kontynuacie. Budynek przystosowano do wspótczesnych potzeb, jego przestrzen stuży nie tylko wystawom, ale tez rekrzeb, aje try czy, po najowze, prodkych i nowych wy jus czy, po na nowsze, produkowa juz masowo. sa gu taze tylko z filmów. Mozna np. podziwiac wytworny lsotta Fraschini. To wlaśnie Mry autem jeźdzlla Gloria Swanson w "Bulwarze Zachodzącego Slonca. Muzeum polączone z centrum konferencyjnym, biblioteką i przestzeniami edukacyjnymi stało się siłą napędową rewitalizacji południowo-wschodniej części miasta.

Cino Zucchi jest też autorem nowej siedziby jednego z najważ niejszych producentów kawy - Nuvola Lavazza ${ }^{27}$. Awangardowy zespol biurowy stanal przy via Bologna, po pólnocnej stronie Corso Regina Margherita. To budynek energooszczędny, zaprojektowany z poszanowaniem srodowiska i z myśla o wygodzie i potrzebach pracownikow. Znajduje się tu także restauracją z wykwintną kuchnią i muzeum, które otwiera przed zwiedzającymi świat kawy i związanych z nią rytuałów. Nowa inwestycja ożywia cześć miasta dotychczas zwiazzana z przemysłem, a teraz będzie rozwijać się pod szyldem zrównoważonego rozwoju. Na terenie nowej siedziby marki Lavazza znajduje sie przestrzeń do organizowania debat, konferencji i imprez kulturalnych, bistro dla pracowników firmy stref archeologiczna oraz budynek Instytutu Sztuk Stosowanych i Designu.

Dowa infrastruktura miast staje sie stopniowo nieodzownym gęstą tkanką śródmiejską. Tak też się dzieje w Turynie. Naj-

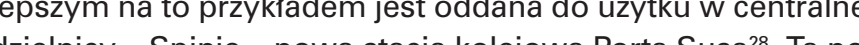
dzeczes - Spinie - nowa sacja ko jowa Porta Susas. Ta nowrzestzen publczn o wielofukca kna strukna a zarazem przestrzen publicna oferująca koncentracje wielu usług, stanowi takze symboliczną bramę między Włochami a Europa Połnocną. Ta "zszywająca" miasto realizacja jest związana z przeniesieniem infrastruktury kolejowej pod ziemię, aby wyeliminować z centrum zabudowy, który dzieli przestrzeń a przez to stanowi barierę dla mieszkańców, dla organizacj komunikacji i dla sprawnego funkcjonowania miasta. Stację zlokalizowano między Corso Inghilterra a Corso Bolzano, z głównym wejsciem od strony Piazza XVIII Dicembre. Całe założenie prowadzi od Piazza Statuo az po wspomniany wcześniej budynek wieżowy Intesa Sanpaolo, sama struktura zaś rozpięta jest pomiędzy budynkiem starego dworca (od północy) aż po planowaną wieżęęo, która ma stanąć na osi catej kompozycji (od południa).
One interesting example of the modernisation of one of the oldest automobile museums in the worldMuseo dell'Automobilie24-is the design by architect was subjected to thorough restoration and renova tion work in 2011, in addition to becoming extended through the addition of a new wing. The new building does not compete with the existing massing, but in only the hosting of exhibitions, but also the recreation of Turin's residents. The exhibition constitutes an attempt at recreating the history of cars, from the

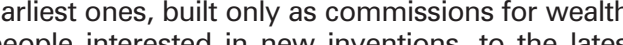
mass-produced models. It also includes models that have not been seen on the streets for a long time and that are currently known only from films. We can, for instance, marvel at the refined Isotta Fraschini. It is vard". The muse m is connected with a conset Boulecentre, a library and educational spaces, becoming
the driving force behind the urban regeneration of the south-eastern part of the city.

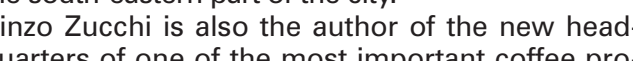
quarters of one of the most important coffee pro-
ducers-Nuvola Lavazza fice complex was built near via Bologna, on the northern side of Corso Regina Margherita. It is an energy-efficient building, designed with respect to and needs of employees. It also houses a restat rant with choice cuisine and a museum, which opens before its visitors the world of coffee and its associated rituals. The new project enlivens a par industry, and which will be developing under the sign of sustainable development from now on. The grounds of the new headquarters of the Lavazza brand also feature a space for the organisation of debates, conferences and cultural events, a bistro
for the company's employees, an archaeological
zone, as well as a building of the Institute of Applied Arts and Design.

new municipal infrastructure is slowly becoming pening in Turin. The best example of this is the new Porta Susa ${ }^{2}$ train station-which has been opened tive, mixed-use structure, which also functions as public space, offering a concentration of numerous services, also constitutes a symbolic gateway
between Italy and Northern Europe ${ }^{28}$. This project, which "binds" the city, is associated with relocating the railway infrastructure beneath ground level in order to eliminate it from the downtown built-up area as it had divided the space and thus consti-
tuted a barrier for the residents, the organisation of circulation and the efficient functioning of the city. and Corso Bolzano, with a main entrance from the side of Piazza XVIIII Dicembre. The entire complex ously mentioned Intesa Sanpaolo tower building while the structure itself is suspended between the building of the old train station (from the north), al the way to the planned tower29, which is meant to
be built on the axis of the entire composition (from the south).

The new station is a node of the first-degree ralway network, being crossed by the underground 
Nowa stacja jest węzłem sieci kolejowej pierwszego stopnia, przejeżdza tędy metro, linie kolei miejskiej oraz pociąg duzej prędkości. Budynek otrzymał futurystyczna, płynna formę tunelu, zrealizowanego ze stali i szkła, o długości 385 metrów i szerokości 30 metrów. Uksztaltowany został ze 108 łuków o zmiennej wysokości - od 3 do 12 metrów (w najwyższym punkcie zadaszenia). Tunel, zaprojektowany na tym samym poziomie co jezdnia taczy bezpośrednio stacje z otaczajacym ia miastem. Projekt nowej stacii Porta Susa traktuje przestrzeń miejsk jako strefe publiczna, w kuśre tracja grón staje sie szklona ga stacja glowe saja mieje scia i paszu: miasto who sho wa staje sie nowym sercen

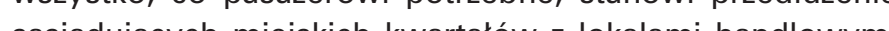

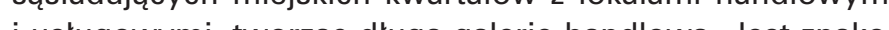
i uslugowymi, morzc duga galie handlowa. Jest znakomitym przykladem koegzystencji awóch bytow. Wchlonięcia nowoczesnej, futurystycznej formy przez starą tkankę miasta, bez uszczerbku dla tej ostatniej.

\section{Podsumowanie}

Krajobraz przemysłowy wszedł na stałe w krąg zainteresowan i problematyki dziedzictwa kulturowego na fali filozofii postmodernistycznej lat 70. Wystarczy przypomnieć sobie wielka dyskusję toczącą się wokoł hal paryskich. Tak się stało z adaptacją opuszczonych olbrzymich terenow po dawnym porcie i dokach w Londynie, Amsterdamie i Rotterdamie ${ }^{31}$. Rewaloryzacja terenow poprzemysłowych generuje miejsca nowych, interesujących kreacji urbanistycznych, zmieniając nie tylko wizerunek obszaru, ale również wpływając pobudzająco na jego rozwój gospodarczy. Dziś stare fabryki, stare osiedla przyfabryczne zaadaptowane do nowej funkcji i uzbrojone $w$ ultranowoczesne obiekty staja sie elementem stanowiącym o nowej jakości przestrzeni miejskiej lub wrecz przyczyniaja sie do podnoszenia tzw. City Branding czyli, umarkowienia miasta"32. A Turyn jest modelowym przykładem tego zjawiska.

Wytrawna pótnoc ( jest daleka od pocztówkowych rumieńców, ale przyjazna. Turyn też bywa przyjazny. Choć surowy, ka-

railway, municipal railway lines and high-speed trains. The bulling recelved the futuristic, fluid form of a tunnel, buitc out of steel and glass, with It was designed to be composed of 108 arches of differing height-from 3 to 12 metres (at the highest point of the roof). The tunnel, designed on the same height level as the carriageway, directly links the new Porta Susa station treats urbe design of a public zone, in which the main station becomes a glass gallery fulfilling the role of a crossing and a passage: the city "enters" the station and the staSusa is equipped with everything of the city. Port need, constituting an extension of the nearby urban blocks with commercial and service spaces creating a long shopping gallery. It is an excellent example of the co-existence of two entities: the ue, without damage to the latter.

Conclusion

The industrial landscape has entered the field of interest and the subject matter of cultural heritage 1970 's for good. It is enough to mention the grea discussion involving the Parisian halls. It was so with the adaptation of the enormous abandone areas of the former port and docks in London, tion of post-industrial areas generates places for new, interesting works of urban design, changin not only the image of an area, but also acting a a stimulant to its economic development. Today to new forms of use and equipped with ultramed ern structures, become elements that signify a new quality of urban space or even outright lead to the improvement of so-called City Branding ${ }^{31}$-Turi being a model example of this phenomenon. it is friendly. Turin is also friendly at times. Although austere, built of stone and without charm, in which even a gallery of modern art is built "differently". There is not a lot of such cities in the world. Cities truck. This is exactly bhat Turin is. Full to see a food

I1. 2. Turyn, fragment panoramy miasta z widokiem na Piazza Vittorio Veneto od strony kościota Gran Madre di Dio, fot. B. Malinowska-Petelenz
III. 2 Turin, fraggent of the city's panorama with a view of Piazza Vittorio Veneto from the side of Gran Madre di Dio Church, phot. by: B. Malinow-
ska-Petelenz

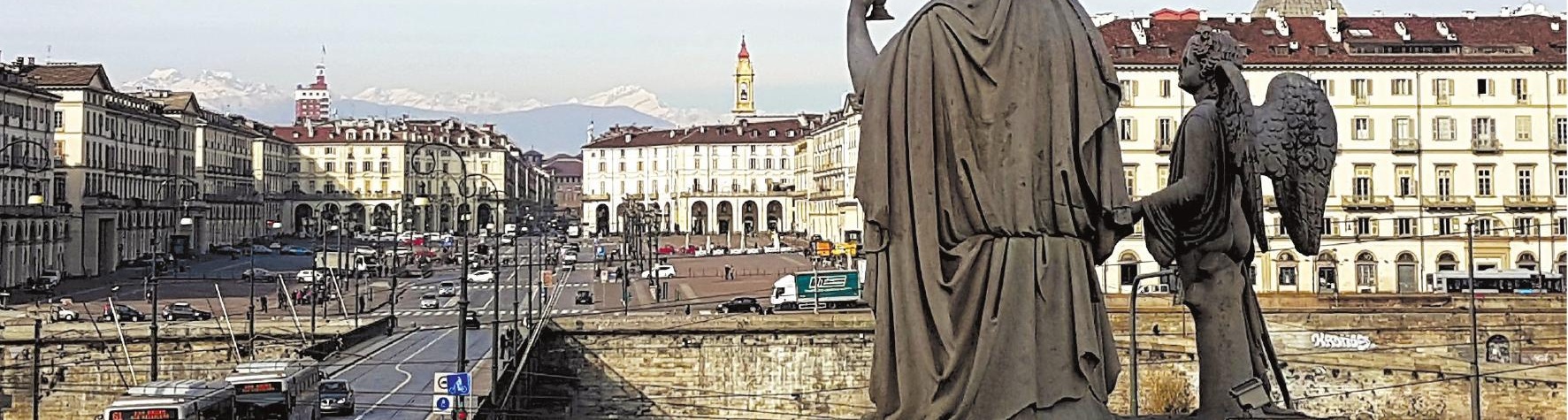

mienny i pozbawiony zalotnosci, w ktorym nawet galeria sztuki na świecie. Miast w których łatwiej o ksiażkę, niż o food trucki. Taki właśnie jest Turyn. Peten księgarni, antykwariatów, stoisk z albumami i galerii zręcznie balansujących między tradycia a nowoczesności $i a^{33}$. Bo Turyn choć żyje przeszłościa, to potrafi a inteligentnie zagospodarować Miał też szczeście Turyn do amatorów wielkiej sztuki - to tutaj powstała m. in kolekcja $\mathrm{Fe}$ derico Cerrutiego i rodziny Agnellich. Wprawdzie Galleria Civid'Are Modd nie sztuke XIX wieku - cièkie, wielkoform toze malow-

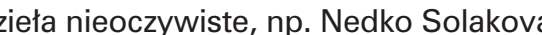

Miasto wciąz efektownie łaczy swe kulturowe dziedzictwo z nowoczesna transformacia zdeindustrializowanej tkank miejskiej. Powstaja tu awangardowe struktury i innowacyjn obiekty z zastosowaniem najnowszych technologii w zgodzie z filozofią zielonej architektury ${ }^{34}$. Powstają wciąż nowe muzea galerie sztuki. Turyn więc staje się miastem coraz bardziej "smart".

PRZYPISY

Whoska nazwa rzeki Pad

Wiecej [W:] F. Corni, Torino Capitale. Una chiave per la lettura della città attraverso i disegni di Francesco Corni, Tipografiia Parena Editrice, Torino 2012
${ }^{4}$ placu wytyczonego w 1587 r., by mogrty sie tu odbywać turnieje rycerskie

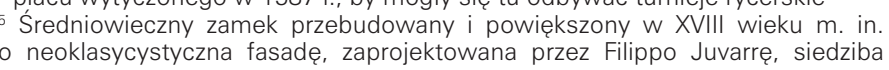

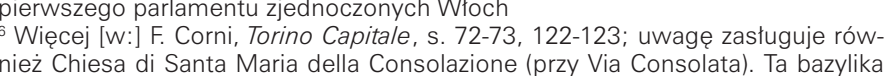

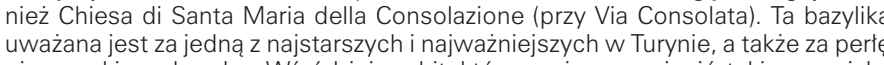
piemonckiego baroku. Wsród jej architektów można wymienić takie nazwiska

jak: Carlo Ceppi, Filippo Juvarrai i Guarino Guari
गF. Corni, Torino Capitale, op.cit, s. $258-259$

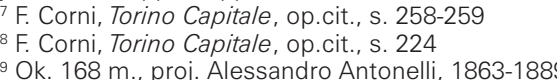

S Swiatynia zostata zbudowana na polecenie Wiktora Amadeusza II, ksiecia Pie sko-hiszpańskich oblegajaccych Turyn w 1706 ?

"I. Corni, Torino Capitale, op. cit., s. 93

i Wiecej [w: I Z. K. Zuziak, Urbanistyka i dziedzictwo kultur. Strategie, aktorzy ${ }_{9-32}{ }^{2}$

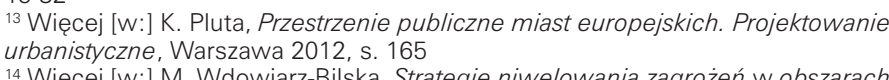

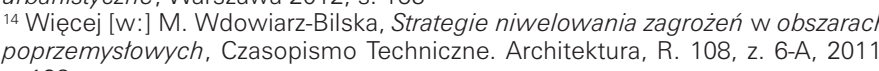
poprzemystowych, Czasopismo Techniczne. Architektura, R. Po,
S1 193 Parco Dora, 2004 - 2012, Landscape Architecture: Latz + Partner

Mario Botta Architetti, 2004-2006

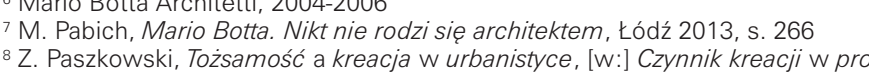

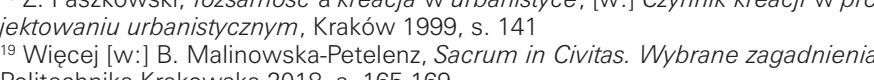

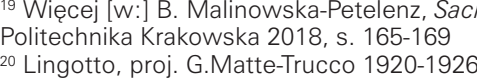

20 Lingotto, proj. G.Ma
${ }^{21}$ Renzo Piano, 1989

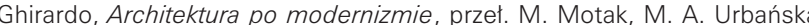

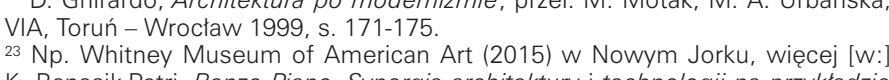
23 Np. Whitney Museum of American Art (2015) w Nowym Jorku, wiecee [W]
K. Banasik-Petri, Renzo Piano. Synergia architektury i technologii na przzktadzie

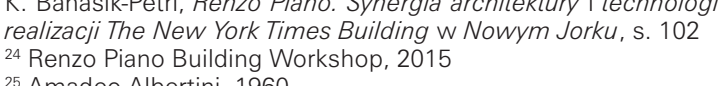

${ }^{26}$ Cino Zucchi Architetti, 2011

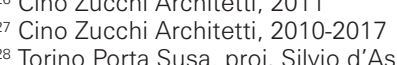

29 Torino Porta Susa, proj. Silvio d'Ascia Architecture, 2013
29
Stacja ma strategiczne znaczenie dla catej wtoskiej sieci kolejowej - główny Przystanek na linii Paryz-Rzym
${ }_{30}$ Proj. Silvio d'Ascia Architecture i AREP

31 E. Wectawowicic-Gyurkovich, Nowe życie architektury, Wiadomości Konserwa-
lorskie 20/2006, s. 32 antique shops, stands with albums and galleries that deffly find their balance between tradition and in the past it can dever of turin, although it lives rin was also lucky when it came to lovers of grea art-it is here that, among others, the collections of Federico Cerruti and the Agnelli family were established. In truth, the Galleria Civica d'Arte Modern Centh-century art-heavy, large-format painting and sculptures, but also twentieth-century avantgarde and quite contemporary, unobvious works, e.g. by Nedko Solakov.

city still impressively combines its cultura industrialised urban tissue. Avant-garde structureand innovative buildings featuring the latest technologies are being built here, in accordance with the philosophy of green architecture 33 . New musethus becoming an increasingly "smart" city.

ENDNOTES 1 Named Julia Augusta Teurinensis
2More on the subject lin: F. Corni, Torino Capitale. Una chia-
ve per Il lettura della citta a attraverso i i disegni di Francesco a square delineated in 1587 so that knight

could be held here.

the eigheenth century to include, among others, a neoclassicis
acade, designed by filippo Juvarra, the headquarters of the hirst parliament of unified ltaly.
${ }^{5}$ More on the subject [in:] F. Corni, Torino Capitale, p. 72-73, 1More on the subject lin:! F. Corni, Torino Capitale, p. $72-73$,
122-123; of note is also Chiesa di Santa Maria della Conso-
lazione (near Via Consolata). The basilica is considered to be one of the oldest and most important in Turins, as well as
bation a pearl of Piedmontese Baroque. Among its architects are
such names like: Carlo Ceppi, Filippo Juvarra and Guarino such names like: Carlo Ceppi, Filippo Juvara an
Guarini.
6 . Corni, Torino Capitale, op.cit., p. $258-259$

F. Corni, Torino Capitale, op.cit., p. 224
8 Ca. 168 m., designed by Alessandro Antonelli, 1863-1889,

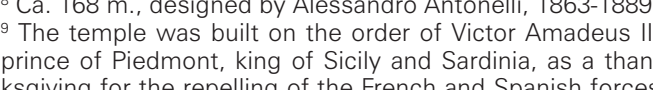
ksgiving for the repelling of the French and Spanish forces
that laid siege to Turin in 1706 . "F. Corni, Torino Capitale, op.cit., p. 93
"More on the subject lin:l Z. K. Zuziak, dzictwo kultury. Strategie, aktorzy i struktury w labiryntach
miejskosci, Wiadomosci konserwatorskie 43/2015, p. 19-32 More on the subject lin:] K. Pluta, Przestrzenie publiczne
miast europejskich. Projektowanie urbanistyczne, Warszawa

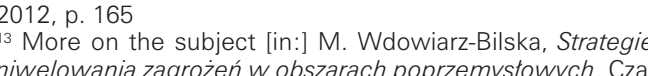

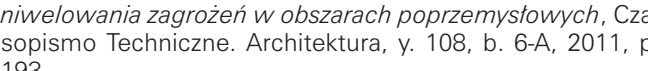
193 Parco Dora, 2004 - 2012, Landscape Architecture: Latz 15 Marnio Botta Architetti, 2004-2006
${ }^{16}$ M. Pabich, Mario Botta. Nikt nie

. Nikt nie rodzi sie architektem. 17 Z. Paszkowski, Tozisamość a kreacja w urbanistyce, [w:]
Czynnik kreacji $w$ projektowaniu urbanistycznym, Kraków

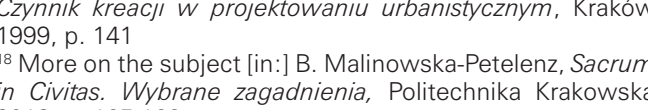
in Civitas. Wybrane zagadnienia, Politechnika Krat
2018, p. $165-169$
19 Lingotto, designed by G.Matte-Trucco 1920-1926

20
21
21 Denzo . Girardoo, Architektura po modernizmie, transl. by M.
Motak, M. A. Urbańska, VIA, Toruń - Wroctaw 1999, p. 171-

22 E.g. Whitney Museum of American Art (2015) w Nowym

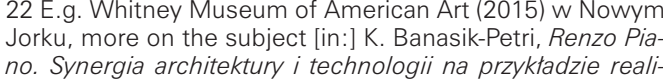
no. Synergia architektury i technologii na przyktadzie reali
zacji The New York Times Building w Nowym Jorku, p. 102
${ }^{23}$ Renzo Piano Building Workshop, 2015 ${ }^{23}$ Renzo Piano Building W
${ }^{24}$ Amadeo Albertini, 1960 
${ }^{32} \mathrm{E}$. Kuryłowicz, Dzieło-arcydzieło a ikona we współczesnym mieście. Detronizacja czy nobilitacja dla idoli XXI wieku? Czasopismo Techniczne. Architektura, vol. 105, nr 6-A, 2008, s. 99-104

${ }^{33}$ Cyt. za A. Petelenz, Turyn - odpowiedź na pop-turystyke, Gazzetta Italia nr 68, 2018, s. 38

${ }^{34} \mathrm{~Np}$. słynny już Condominio 25 Verde w Turynie projektu Luciano Pia otwarty w 2014 zaliczany do tzw. bioarchitektury, więcej [w: P. Haupt, Naturalne elementy kompozycji w kształtowaniu wspótczesnej przestrzeni miejskiej. Relacje budynku z otoczeniem, Monografia 514 Kraków 2016, Politechnika Krakowska, s. 96-99; M. Petelenz, Ekologiczne nawierzchnie i zieleń w zrównoważonym środowisku miejskim, [w:] Rolnictwo miejskie oraz ekologiczna i zielona architektura w miastach europejskich ze szczególnym uwzględnieniem rozwiązań wiedeńskich, Monografie PK, seria Architektura, Kraków 2018, s. 39

\section{LITERATURA}

[1] Banasik-Petri K., Renzo Piano. Synergia architektury i technologii na przykładzie realizacji The New York Times Building w Nowym Jorku, KNUV 2017: 4(54)

[2] Corni F., Torino Capitale. Una chiave per la lettura della città attraverso i disegni di Francesco Corni, Tipografia Parena Editrice, Torino 2012

[3] Ghirardo D., Architektura po modernizmie, przeł. M. Motak, M. A. Urbańska, VIA, Toruń - Wrocław 1999

[4] Haupt P., Naturalne elementy kompozycji w kształtowaniu wspótczesnej przestrzeni miejskiej. Relacje budynku z otoczeniem, Monografia 514, Politechnika Krakowska, 2016

[5] Juskowiak P., Gentryfikacja jako gentryfikcja. Artystyczny sposób produkcji i restrukturyzacja miast, http://www.academia. edu/1809207/Gentryfikacja jako gentryfikcja. Artystyczny sposób_produkcji_i_restrukturyzacja miast Gentrification as Gentrifiction._Artistic_Mode_of_Production_and_Urban_Restructuring, dostęp: $10 . \overline{0} 7.2018$

[6] Juzwa N., Tradycja współczesnej architektury przemysłowej, Zeszyty Naukowe Politechniki Śląskiej, Seria: Architektura, z. 36, 1997

[7] Kuryłowicz, Dzieło-arcydzieło a ikona we wspótczesnym mieście. Detronizacja czy nobilitacja dla idoli XXI wieku? Czasopismo Techniczne. Architektura, vol. 105, nr 6-A, 2008

[8] Malinowska-Petelenz B., Sacrum in Civitas. Wybrane zagadnienia, Wydawnictwo: Politechnika Krakowska, 2018

[9] Pabich M. Mario Botta. Nikt nie rodzi sie architektem, Łódź 2013

[10] Paszkowski Z., Tożsamość a kreacja w urbanistyce, [w:] Czynnik kreacji w projektowaniu urbanistycznym, Kraków 1999

[11] Petelenz A., Turyn - odpowiedź na pop-turystykę, Gazzetta Italia $\mathrm{nr} 68,2018$

12] Petelenz M., Ekologiczne nawierzchnie i zieleń w zrównoważonym środowisku miejskim, [w:] M. Drożdż-Szczybura, M. Petelenz, A. Korzeniowska, Rolnictwo miejskie oraz ekologiczna i zielona architektura w miastach europejskich ze szczególnym uwzglednieniem rozwiazań wiedeńskich. Monografie PK, seria Architektura, Kraków 2018

[13] Pluta K., Przestrzenie publiczne miast europejskich. Projektowanie urbanistyczne, Warszawa 2012

14] Wdowiarz-Bilska M., Strategie niwelowania zagrożeń w obszarach poprzemysłowych, Czasopismo Techniczne. Architektura, R. 108, z. 6-A, 2011

[15] Węcławowicz-Gyurkovich E., Nowe życie architektury, Wiadomości Konserwatorskie 20/2006

[16] Zuziak Z. K., Urbanistyka i dziedzictwo kultury. Strategie, aktorzy i struktury w labiryntach miejskości. Wiadomości konserwatorskie $43 / 2015$
${ }^{25}$ Cino Zucchi Architetti, 2011

${ }^{26}$ Cino Zucchi Architetti, 2010-2017

27 Torino Porta Susa, design by. Silvio d'Ascia Architecture, 2013

28 The station of strategic significance to the entire Italian railroad network -it is the main stop along the Paris-Rome railway line.

${ }^{29}$ Design by Silvio d'Ascia Architecture i AREP

30 E. Węcławowicz-Gyurkovich, Nowe życie architektury, Wiadomości Konserwatorskie 20/2006, p. 32

31 E. Kuryłowicz, Dzieło-arcydzieło a ikona we wspótczesnym mieście. Detronizacja czy nobilitacja dla idoli XXI wieku? Czasopismo Techniczne. Architektura, vol. 105, iss. 6-A, 2008, p. 99-104

32 Quoted from A. Petelenz, Turyn - odpowiedź na pop-turystyke, Gazzetta Italia iss. 68,2018, p. 38

${ }^{33}$ E.g. the already famous Condominio 25 Verde in Turin, designed by Luciano Pia and opened in 2014, considered to be a work of so-called bioarchitecture, more on the subject [in:] P. Haupt, Naturalne elementy kompozycji w kształtowaniu współczesnej przestrzeni miejskiej. Relacje budynku z otoczeniem, Monograph 514 Kraków 2016, Politechnika Krakowska, p. 96-99; M. Petelenz, Ekologiczne nawierzchnie i zieleń w zrównoważonym środowisku miejskim, [in:] Rolnictwo miejskie oraz ekologiczna i zielona architektura w miastach europejskich ze szczególnym uwzględnieniem rozwiązań wiedeńskich, CUT monograph, series: Architecture, Kraków 2018, p. 39

\section{BIBLIOGRAPHY}

[1] Banasik-Petri K., Renzo Piano. Synergia architektury i technologii na przykładzie realizacji The New York Times Building w Nowym Jorku, KNUV 2017; 4(54)

[2] Corni F., Torino Capitale. Una chiave per la lettura della città attraverso disegni di Francesco Corni, Tipografia Parena Editrice, Torino 2012

[3] Ghirardo D., Architektura po modernizmie, transl.. M. Motak, M. A. Urbańska, VIA, Toruń - Wrocław 1999

[4] Haupt P., Naturalne elementy kompozycji w kształtowaniu wspótczesnej przestrzeni miejskiej. Relacje budynku z otoczeniem, Monograph 514 , Politechnika Krakowska, 2016

[5] Juskowiak P., Gentryfikacja jako gentryfikcja. Artystyczny sposób produkcji i restrukturyzacja miast, http://www.academia.edu/1809207/ Gentryfikacja jako gentryfikcja. Artystyczny sposób produkcji i restrukturyzacja miast Gentrification as Gentrifiction. Artistic Mode of Production and Urban Restructuring, retrieved on: 10.07 .2018

[6] Juzwa $\bar{N}$., Tradycja wspótczesnej architektury przemystowej, Zeszyty Naukowe Politechniki Śląskiej, Series: Architecture, b. 36, 1997

[7] Kuryłowicz, Dzieło-arcydzieło a ikona we współczesnym mieście. Detronizacja czy nobilitacja dla idoli XXI wieku? Czasopismo Techniczne. Architektura, vol. 105, iss. 6-A, 2008

[8] Malinowska-Petelenz B., Sacrum in Civitas. Wybrane zagadnienia, Publisher: Politechnika Krakowska, 2018

Pabich M., Mario Botta. Nikt nie rodzi się architektem, Łódź 2013

[9] Paszkowski Z., Tożsamość a kreacja w urbanistyce, [in:] Czynnik kreacji w projektowaniu urbanistycznym, Kraków 1999

[10] Petelenz A., Turyn - odpowiedź na pop-turystykę, Gazzetta Italia iss. 68,2018

[11] Petelenz M., Ekologiczne nawierzchnie i zieleń w zrównoważonym środowisku miejskim, [in:] M. Drożdż-Szczybura, M. Petelenz, A. Korzeniowska, Rolnictwo miejskie oraz ekologiczna i zielona architektura w miastach europejskich ze szczególnym uwzględnieniem rozwiązań wiedeńskich, CUT Monographs, series: Architecture, Kraków 2018

[12] Pluta K., Przestrzenie publiczne miast europejskich. Projektowanie urbanistyczne, Warszawa 2012

[13] Wdowiarz-Bilska M., Strategie niwelowania zagrożeń w obszarach poprzemysłowych, Czasopismo Techniczne. Architektura, y. 108, b. 6-A, 2011

[14] Węcławowicz-Gyurkovich E., Nowe życie architektury, Wiadomości Konserwatorskie 20/2006

[15] Zuziak Z. K., Urbanistyka i dziedzictwo kultury. Strategie, aktorzy i struktury w labiryntach miejskości, Wiadomości konserwatorskie 43/2015 